\title{
The relationship between legal systems
}

\section{Gil Carlos RODRÍGUEZ IGLESIAS*}

I. I have decided to address the relationships between legal systems as the subject of my acceptance speech. Both the choice of subject and how I will approach it are conditioned by my professional background, which has essentially been shaped by three main factors: my status as an international law professor, my specific interest in European Community law, and my judicial activity over the last i5 years.

Needless to say, I do not intend to develop or even outline this topic as a thesis, but rather to lay out a few personal thoughts on it.

To this end, I will approach the subject successively from four different perspectives: the traditional perspective of the relationship between international law and domestic law, the specific perspective of the relationship between European Community law and the domestic law of the Member States, the perspective of the relationship between international law and European Community law, and, finally, the perspective of the growing interrelationship between different national and international legal systems.

Before I begin, I would like to underscore that a key premise of all my thoughts on these matters is the importance of legal pluralism or the pluralism of legal systems, which is an objective state of affairs. In my opinion, one important consequence of this legal pluralism is that there is not always a single legally correct solution to the conflicts that arise as a result of the interactions between the different legal systems. Instead there is a plurality of solutions, in keeping with the pluralism of the legal systems, whose harmonization or convergence cannot always be achieved through legal logic alone. This is something I always stress when referring to the relationship between European Community law and the constitutional law of the Member States, a passionately contested topic in the literature and one I will return to shortly.

2. With regard to the classical issue of the relationship between international law and domestic law, the traditional perspective, based on the divide in the literature between monism and dualism, has given way to a more empirical analysis of the legal reality. This new approach makes it possible to regard today as something non-controversial the fact that international rules are generally received and implemented in accordance with each state's legal system, that the various legal systems provide for diverse solutions in this regard based

\footnotetext{
* $\quad$ i946 - 2009. Professor of Public International Law and International Relations, Universidad Complutense de Madrid. Judge (1986 - 2003) and President (1994-2003) of the European Union Court of Justice.

This (adapted) article was the Lectio before the University of Oviedo when admitted as Doctor Honoris Causa on 25 May 200I; and it was originally published as 'Discurso de investidura como doctor honoris causa por la Universidad de Oviedo de Gil Carlos Rodríguez Iglesias, Presidente del Tribunal de Justicia de las Comunidades Europeas pronunciado el 25 de mayo de 200I', Revista Jurídica Española La Ley (200I) I702-I7o6. Translated by by Kari Friedenson.
} 
on monist or dualist conceptions, and that the problems encountered within each legal system often depend on the type of international rule being received and, in particular, whether it arises from customary international law, treaty-based law or regulations established by an international organization.

Setting aside, for a moment, the matter of European Community law, we can see that the progressive development of international law has afforded domestic judges an increasingly important role in its implementation whilst reinforcing the unavailable nature of certain principles. The most important innovations in this area are, in my view, those resulting from the recognition of the existence of imperative norms of international law - jus cogens norms - and of international norms establishing individual rights and obligations, particularly human rights norms and the norms categorizing international crimes and determining individual criminal responsibility.

However, notwithstanding the growing overlap between international law and domestic law in the areas governed by such international norms, the imperative nature of those norms, or the fact that they are intended to confer individual rights and create individual obligations, this process obliges states to adopt monist solutions for the reception and implementation of these norms in their respective domestic legal systems.

In this regard, beginning with a 1976 judgment, the European Court of Human Rights has acknowledged that the European Convention on Human Rights does not dictate for the Contracting States any given manner of ensuring the effective implementation of any of the Convention's provisions within their internal law, even though the Court itself has recalled that incorporating them into domestic law is the most effective way to do so. Furthermore, it is widely recognized that domestic rules are crucial for the criminal sanctioning of international crimes, in terms of the classification and criminalization of punishable behaviours and the very existence of universal criminal jurisdiction, as well as the possibility of extradition to a state whose criminal jurisdiction lacks a territorial basis. The various judgments delivered in Spain and the United Kingdom in the well-known Pinochet case are extremely illustrative in this regard.

Additionally, with a few notable exceptions, such as the r949 Geneva Conventions on international humanitarian law (and, according to a controversial interpretation, the Convention on Torture), international treaties recognizing universal criminal jurisdiction for the prosecution of certain conducts do not usually establish the compulsory nature of that prosecution, but rather simply acknowledge the legitimacy of pursuing it. Thus, the progressive development of international law has not yet crystallized in the sense sought by the International Law Commission's Draft Code of Crimes against the Peace and Security of Mankind, Article 8 of which provides that all States Party shall take the necessary measures to establish their jurisdiction over the crime of genocide, crimes against humanity and war crimes, regardless of where or by whom they were committed, and Article 9 of which provides that the State Party in whose territory an individual alleged to have committed a crime is found shall extradite or prosecute that individual.

3. Let us now look at the relationship between European Community law and domestic law. I will begin with a few preliminary observations to clarify my conceptual and methodological 
assumptions.

With regard to the controversial issue of the legal nature of European Community law, my personal position, which I have had the opportunity to express on several occasions, can be summarized as follows. The appropriate legal classification of European Community law is that of a specific international law system; however, the essential traits of this legal system are not determined by this classification, but by the content of the treaties constituting the primary law, as well as the subsequent evolution of the European Community legal phenomenon, which cannot be separated from its theoretical understanding.

As for the content of the primary law, the system's most salient aspects are, first, the ambitious integration agenda set forth in the treaties and enriched by their successive modifications, and, second, the institutional dimension of the European Communities, one of whose essential elements is the existence of a Court of Justice responsible for enforcing the law in the interpretation and application of the treaties and endowed with the necessary powers to fulfil this mission effectively. Accordingly, the Court of Justice has played a key role in the evolution of European Community law as a core element for coordinating the process of dialectical interaction between legal theory and application of the law.

The case law of the Court of Justice has thus shaped the elements today considered characteristic of European Community law, namely, first, the fundamental principles of direct effect, primacy and state responsibility for damage caused to individuals on account of noncompliance with European Community law, and, second, the progressive constitutionalization of the system in the sense that the treaties are conceived of and applied as a Constitution of the European Community.

This is not the place for an extended discussion of these well-known principles. What I wish to underline now is that the principles of direct effect and primacy have led to the establishment, as a major specificity of European Community law, of a monist solution for the relationship between the European Community legal order and the domestic law of each Member State. In short, unlike most international norms, the aforementioned principles of European Community law determine for themselves how the norms of this legal order are to be incorporated into the internal order, thereby precluding any sort of dualist solution.

The dramatic incompatibility of dualist techniques with European Community law was on display in the ingenious solution that the United Kingdom found, at the time of its accession, to overcome the seemingly insurmountable stumbling block of the principle of parliamentary sovereignty. The European Communities Act relativized that principle, stating that parliamentary acts could not prevail over European Community law, thereby ensuring the latter's primacy over both previous and subsequent acts of the British Parliament.

Certainly, this law can be interpreted in a dualist light if one considers that the relativization of parliamentary sovereignty that it brings about is valid only so long as Parliament does not expressly decide to question the pre-eminence of European Community law. I will not go into greater detail on this issue of British "constitutional" law. Allow me simply to cite the opinion of Professor MACCORMICK, who, in I993, said that such an exception to the primacy of European Community law over acts of Parliament is dubious and subject to possible customary evolution, adding that whilst it would probably have been almost 
unanimously endorsed in 1972, and might even have continued to be so at the time he was writing (i.e. in 1993), it was quite likely that at some point in the next century (i.e. the 2Ist century) it would come to be regarded as antediluvian heresy.

The exclusion of dualist solutions in the relations between European Community law and domestic law, however, is not absolute, for the effectiveness of the principles of direct effect and primacy proclaimed by the Court of Justice, and, in short, of all European Community law, in each state's internal order is critically conditioned by the attitudes of national jurisdictional bodies, which are responsible, in their areas of territorial and functional jurisdiction, for enforcing European Community norms.

In this regard, it is worth noting, in general, that national constitutional and supreme courts have welcomed and accepted the basic principles of organization between European Community law and the domestic systems and have contributed to their general acceptance in the national legal systems. Today, both the direct effect and the primacy of European Community law over infra-constitutional domestic law seem to be generally accepted, although, to reach this point, it was first necessary to overcome various dualist obstacles in some states arising, in particular, from national conceptions of the supremacy of the legislative branch or of the position of administrative or ordinary judges in relation to the law.

However, dualist elements remain in the approaches of some constitutional courts or supreme courts with constitutional jurisdiction to the relationship between European Community law and the respective country's constitutional law.

In short, the recognition of the primacy of European Community law over domestic law does not include the absolute and unconditional nature with which the Court of Justice seems to have conceived of that primacy in its case law. In fact, unlike some supreme courts, such as the Belgian Council of State, no constitutional court has expressly endorsed the Court of Justice's conception of this primacy.

In contrast, some constitutional courts have identified constitutional limits to the Court of Justice's doctrine, originating in fundamental principles of their respective constitutional system, especially in matters of fundamental rights and powers.

However, by and large, the constitutional and supreme courts of the various Member States have managed to satisfactorily resolve the new problems of coordination between legal systems posed by the intensity of the integration of European Community law into domestic law. In most cases, they have reached solutions consistent with those established by the Court of Justice, although with different reasonings, in which, naturally, reasons grounded in the respective constitutional law are decisive.

In my opinion, in the current stage of European integration, characterized, in the legal arena, by the relative reciprocal autonomy of the national and European Community legal systems, despite their multiple overlaps, and by the separation of their jurisdictional bodies, which are not organized in a single hierarchical relationship, the dramatic conflict between the demands of the European Community system and those of each Member State's constitution does not lend itself to a logically satisfactory solution, as both European Community law and national constitutional law assert their own primacy.

However, this dramatic conflict is actually purely hypothetical, since the fundamental 
values of the national constitutions are shared and integrated into European Community law as general principles common to the Member States' legal systems.

As I noted at the start, legal logic is therefore not enough to avoid these types of conflicts. It is also necessary to use common sense, which, in my view, is an essential element of both legal theory and the practice of law.

4. I will now turn to the perspective of the relationship between international law and European Community law, i.e. to how non-European Community international rules that are binding on the European Communities are inserted and implemented in the European Community legal system. I am referring, of course, not so much to international rules regulating internal aspects of the Community's functioning, but to international sources arising from the external relations that result from the European Communities' participation, as an actor, in the universal international community, which is premised, at the legal level, on their status as a subject of international law.

The problems posed in this type of relationship are basically the ones posed by the relationship between international law and the domestic law of each state: criteria for the reception of international norms, hierarchical position of the international norms received, and the power of the various domestic bodies to apply and interpret international law. It is thus also necessary to seek the solution within the framework of European Community law itself, which, for these purposes, can be regarded as a "domestic order".

Article 300 of the Treaty establishing the European Community regulates with considerable detail the procedure for the conclusion of international agreements between the Community and third states or international organizations. However, when it comes to the internal effects of the rules set out in those agreements, it merely states, in paragraph 7 , that "Agreements concluded under the conditions set out in this Article shall be binding on the institutions of the Community and on Member States."

We must thus turn to the Court of Justice's case law, which, admittedly, is not as clear in this area as in that of the relationship between European Community law and domestic law.

With regard to general international law, there is a clear monist trend. The Court has recalled on several occasions that the European Community's powers must be exercised in accordance with international law. In the Poulsen judgment, from I992, the Court interpreted the rules relating to European Community jurisdiction in matters of fisheries in light of the texts codifying the rules recognized by international custom. The Court has likewise referred multiple times to the Vienna Convention on the Law of Treaties. The most remarkable example of this case law is the Racke judgment, from 1998 , in which the Court of Justice states that the customary international law rules concerning the termination and suspension of treaty relations as a result of a fundamental change of circumstances are binding upon the Community institutions and are part of the Community legal order. It further recognized the power of justiciable parties to invoke those rules to contest the validity of a European Community regulation.

The case law also enshrines a monist solution with regard to the reception of treaty-based international law. As the Court indicated in the Haegeman judgment from i974, the agreements concluded by the Community form an integral part of Community law from the date they 
come into force. It used this circumstance to justify its own jurisdiction to interpret such agreements and, in particular, to give preliminary rulings.

The case law concerning the determination of the internal effects of international conventions that are binding upon the Community is more complex.

Not only does the Court attribute an interpretive value to treaty-based international law rules in the sense that they should be taken into account for the purposes of interpreting the related secondary European Community law rules. Under certain conditions, it moreover recognizes that they have a direct effect - in the sense that they create rights that individuals can invoke before a judge - and accepts the potential invalidity of European Community acts that are incompatible with such treaty-based rules.

In this regard, I would like to specify that, although the distinction is far from clear in the case law, in my view, the ability of international rules to be invoked as a parameter of European Community legality is not based on a direct effect in the sense that I just explained.

I will not stop here to examine the criteria developed by the case law for recognizing such effects. What interests me is that these criteria involve analysing both the specific provision in question and the agreement as a whole. Thus, the direct effect or ability of an act to be grounds for invalidity has been rejected not only because the provision essentially served "to set out a programme" (Demirel judgment) or was "indicative" (Compassion in World Farming judgment), but also because, even if they were clear and precise, certain features of the agreement containing the rules prevented such a judicial application.

The more recent case law on the World Trade Organization is the best-known example of this latter type of situation. The impossibility for WTO rules to grant rights to individuals or be used as rules of control in disputes over European Community acts is due to considerations related to the agreement system in question: its "flexibility", which allows for negotiated solutions to be sought in case of non-compliance; its striking differences with bilateral agreements on "special relations of integration" or agreements intended precisely to deliver development aid through asymmetrical obligations; and, finally, the imbalance that would arise if the Community were to allow the acts of European Community institutions to be subject to control by the WTO agreements, when its main trade partners do not allow for any such possibility. All these considerations must be understood in the light of the logically preliminary finding that international law does not require the parties to such agreements to apply them directly as a source of objective rights or as a parameter of internal legality.

The case law only allows for the validity of a European Community act to be subject to control by WTO rules in two cases: if the Community intended to comply with a specific obligation undertaken in that framework (Nakajima judgment) or when the Community act expressly refers to specific provisions of the agreement in question (Fediol judgment). In such cases, the possibility for the judge to use those international rules crucially depends on a certain willingness of the institutions to submit to them, as expressed in an act of secondary law.

The dualist basis for this case law is clear, as is that of the case law enshrining the possibility of a posteriori control of the legality of the conclusion of international agreements by the Community. 
Used on several occasions in the r99os, this a posteriori control is formally exercised over the act of approval of the international agreement, but nullification of the act of approval undeniably leads to a situation in which an international rule that is in force and is binding on the European Community in international law ceases to apply in the European Community legal order once the instrument of conclusion has been nullified.

These dualist elements found in the Court of Justice's case law on the relationship between treaty-based international law and European Community law stand in contrast with the radical monism of its case law on the relationship between European Community law and the domestic law of the Member States.

However, this contrast makes sense when one considers that, in the latter relationship, the monism arising from the basic principles of European Community law is not only the result of the application of certain legal techniques concerning the relationships between legal orders, but also a corollary of the conception of the European Community as a community not just of states, but also of peoples and citizens, a conception which, unfortunately, certainly cannot be expanded to include contemporary international society in general or the WTO in particular.

5. Finally, I would like to compare the relationship between the essentially regulatory phenomena of the relationships between internal and international legal systems to which I have just referred and a different kind of phenomenon, namely, that of the growing interrelationship between the different legal systems, both national and international. It is a universal phenomenon that, however, manifests with particular intensity in the European sphere, to which I will restrict these considerations, which I already discussed in a talk I gave on the formation of European law at the Deutschen Juristentag in 1998.

Beyond the legal unification resulting from European Community law and the European Economic Area, there has been a "Europeanization" of legal theory and growing convergence between the different legal orders. HÄBERLE, in particular, has studied this phenomenon in the area of constitutional law, referring to it as the "common European constitutional law", which he describes as "a growing set of constitutional principles common to the different national constitutional principles". In his view, such concordant principles are, in part, found in the national constitutional texts and unwritten constitutional law of the various European states and, in part, spread throughout Europe via European law, that is, European Community law, the European Convention on Human Rights, the rules of the European Council and even, from a trans-Atlantic perspective, the rules of the Organisation for Security and Co-operation in Europe.

For HÄBERLE, these common European constitutional principles are more than mere coincidental and explicit parallelisms or similar regulatory conceptions. They entail the existence in the different constitutional states of something common, concordant and assumed at the deepest level of their legal culture, something that goes beyond mere positive law. This convergence, which leads to the proliferation of common regulatory elements, has been extensively documented by research in the field of not only constitutional law, but also administrative law and private law.

To the extent that this Europeanization goes beyond the sphere of European Community 
law or the European Economic Area, it is more of a cultural phenomenon than a positive legal one. However, it has vital consequences for the content of positive law.

In conclusion, I would like to underscore that the reciprocal influence between legal systems, the reorganization of public power in Europe and the defence of certain shared political and social values give rise to a complementarity between the legal systems that calls for a new approach: it is increasingly difficult to understand legal systems as isolated legal phenomena.

This evolution, which goes beyond the European sphere, poses a challenge for legal science and the teaching of law. Despite the extremely considerable contribution that legal science has made and continues to make to the Europeanization of law and to the formation of a European law, and despite the proliferation of exchange programmes for teaching staff and students, I am convinced that these trends must yet be considerably intensified.

With regard to the teaching of law, curricula must be opened much more both to international and European legal phenomena and to other national legal systems.

Furthermore, the linking of legal science and the teaching of law to a given national legal system must be thoroughly reviewed. 